\title{
Rudolf Richter, Erik G. Furubotn: Neue Institutionenökonomik
}

\section{Eine Einführung und kritische Würdigung, Tübingen, 2010}

\author{
Jürgen G. Backhaus
}

Published online: 28 January 2011

(C) Springer Science+Business Media, LLC 2011

Rudolf Richter and Erik G. Furubotn have just published the fourth edition of their New Institutional Economics in German.

The two octogenerians, before they started their successful co-operation, they had already left their mark on the profession. Furubotn $(* 1923)$ had launched (with Svetogar Pejovich) the new paradigm of the economics of property rights; Richter (*1926) as editor of the traditional Zeitschrift für die gesamte Staatswissenschaft, one of the oldest publications in political economy, took the controversial decision to publish the journal in English. The book is typically published in both English and German, as the authors write the text out in English, which is then translated into German by Monika Streissler. This translation is no small accomplishment in itself as the new terms in institutional economics are first coined in English; then Dr. Streissler finds an appropriate German term.

The bulky (678 pp) new edition also sharpens the approach. It does not consist in just adding positive transactions costs to the standard model. Rather the authors emphasize:

"Institutions are rather social tools by which individuals and groups try to deal with the consequences of incomplete information and bounded rationality. The concept of Pareto efficiency is therefore senseless." (My emphasis; J. B.) p. V.

It can be expected that this substantial text with a minimum of mathematical notations will allow lawyers and other social scientists to become conversant with political economy.

\footnotetext{
J. G. Backhaus ( $\square)$

University of Erfurt, Erfurt, Germany

e-mail: juergen.backhaus@uni-erfurt.de
} 